\section{EXTRACT FROM \\ OBSERVATIONS ON THE YELLOW-FEVER EPIDEMIC AT BERMUDA IN 1864.}

\author{
By THOMAS G. WILSON, F.R.C.S.I.,
} STAFT-BURGEON, R.N.

(Communicated by the Director-Grankal of thr Medical Department OF THE NAVX.)

\section{MICROSCOPIC APPEARANCES.}

With regard to the pathological anatomy of yellow fever, it was observed at the Royal Naval Hospital in Ireland Island during the epidemic of 1864, that the black vomit, whether ejected during life or taken from the stomach after death, presented under the microscope epithelial scales, nuclei, and variously altered blood-discs, sometimes mixed with ingesta.

The blood-discs were generally more or less broken down; some few remained entire, and these were invariably segregated or non-coherent, and generally milled or crenated at the edges, and they presented very distinct central depressions; some were partially broken down, but easily recognised, while others could only be recognised as altered blood-discs by following the different gradations of change between the entire discs and the granular matter. The striking feature here was the tendency of the blood-discs to remain apart; they were never observed (however soon after removal examined) in the aggregated condition which obtains in healthy blood. This tendency to remain apart, as if the cells repelled each other, was observed in the blood which escaped by epistaxis during life, and also in that taken from the heart after death.

Another microscopic appearance observed in the black fluid ejected during life and taken from the stomach after death, as well as in blood which escaped by epistaxis during life and in that which was taken from the heart after death-and immediately covered up in the receiving vessels

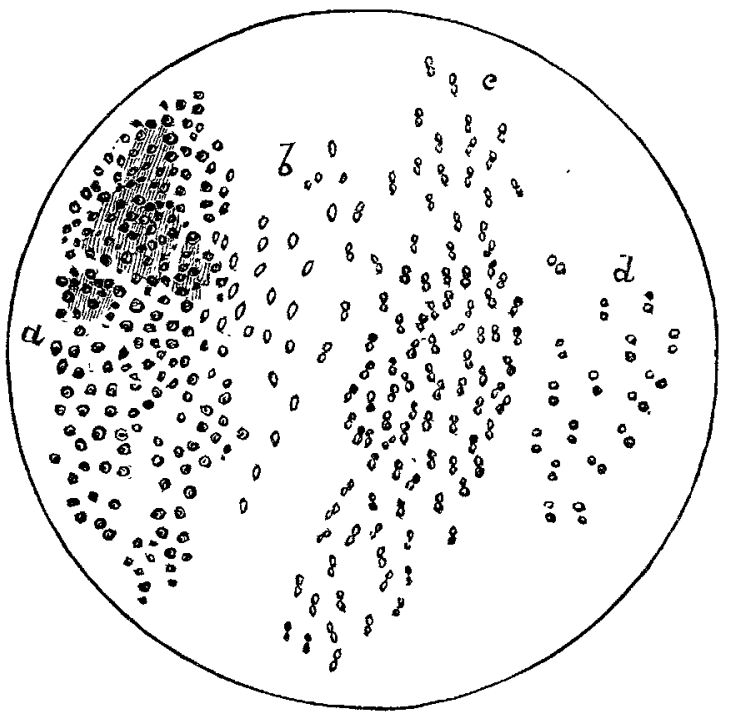

Magnified about 600 diameters.

so as to exclude the air-must be referred to here. A number of small circular cells, much smaller than blood-corpuscles, were seen. These were generally clear, sometimes opalescent, and they moved about freely in every direction. If one of these cells was selected and closely observed for the space of some fifteen minutes, the following changes were seen to occur. The cell, at first circular, became gradually elongated, afterwards contracted in the centre like an hourglass, and ultimately it divided into two distinct cells, each of which, when observed for a sufficient period, was seen to undergo changes similar to those observed in the parent cell.

These simple cells were at first suspected to be air-vesicles made to divide by pressure, but this supposition was soon discarded for the following reason:-The stage of the microscope was placed at an angle of about twenty degrees with the horizon, and the cells alluded to were observed to move about freely in every direction, upwards, downwards, and to either side, whereas, had they been air-cells, they would all have had an upward tendency.

The true pathological value of these phenomena I am not prepared to state. I wish merely to record this observation for the present for as much as may be considered its value.

\section{de ditror}

\section{H O S P T A L P RACTICE, BRITISH AND FOREIGN.}

Nulla autem est alia pro certo noscendi via, nisi quamplurimas et morborum et dissectionum historias, tum aliorum, tum proprias collectas habere, ef inter se comparare.-Mosgagri De Sed.et Caus. MCorb., lib.iv. Proœmium

\section{ST. GEORGE'S HOSPITAL.}

TUMOURS OF BOTH IRIDES; IRIDECTOMIY.

(Under the care of Mr. Brudenell Carter.)

ON Friday, October 24th, Mr. Carter removed a tumour of the iris in a case which is so remarkable that we propose giving a short résumé of what is known of such affections.

Tumours of the iris have been divided into cystic and solid, benign and malignant. Cysts of the iris are of various kinds. Most frequently they consist, as Mr. Bowman* has pointed out, of collections of fluid between the muscular and uveal layer of the iris from traumatic or other causes, and form little semi-transparent tumours, which gradually or rapidly increase in size, and are of a lenticular or pyriform shape. Other cysts seem to be caused by a circumscribed plastic iritis, which gives rise to a horseshoe-shaped posterior synechia, by which the included portion of the iris is cut off from the rest of the posterior chamber and is pushed forwards by the collection of aqueous humour behind it. $\uparrow$ Besides these, there may be congenital sebaceous cysts containing hairs. These have been observed by von Graefe and Mr. John Couper, the latter of whom removed such a cyst a few months ago from the eye of a patient at the Moorfields Ophthalmic Hospital. Lastly, cysticercus cysts of the iris have been met with by Stellwag, Fischer, Teale, and others.

of the solid tumours of the iris the following are the chief :-Condylomata, lipomata, furunculous tumours, telangiectasis, cancer, melanoma, and tubercle. The condylomata generally originate in a parenchymatous inflammation of the iris. They commence as little yellowish swellings surrounded by vessels which, in a short time, extend over its surface. The growth may be no larger than a millet-seed, or may involve a considerable extent of the iris. The masses vary in number and situation, but are mostly found at the inner and superior parts. Microscopically they are said by Virchow, Billroth, Colberg, and von Graefe to be composed of the "granulation tissue" of gummata. The tumours are pedunculated or mammillated, and may be large enough to fill the anterior chamber and lead to ulceration of the cornea by pressure, and even to destructive inflammation of the eyeball. Primary cancer of the iris is exceedingly rare, and usually partakes more or less of a melanotic character, giving rise to a black or brownish mass, which rapidly increases in size, and leads to ulterior destructive changes in the globe. Tubercle of the iris is also very rare, no unequivocal case having ever been observed in the living eye. Until some light is thrown upon the nature of the growths in the following case it is difficult to form a positive opinion. But it may be remarked that they are not likely to be ordinary condylomata, as there is neither history nor trace of any preceding iritis. Carcinomatous disease is rendered doubtful by the fact that the growth has shown itself almost simultaneously in both irides, and has not been characterised by the rapid extension usually observed in such affections. We shall, however, continue to watch the patient, and shall furnish our readers with results of the microscopical examination of the tumour and the further progress of the case.

* Parts concerned in Operations on the Eye, p. 75. London, 1849

+ Wecker : Traité Pratique des Maladies des Yeux, vol, i., p. 428, 2nd ed.

$\$$ Archir für Ophthalmologie, $t$, iii, pt, ii., p. 412. 